\title{
The monkey selfie: copyright lessons for originality in photographs and internet jurisdiction
}

\author{
Andrés Guadamuz \\ University of Sussex, Brighton, United Kingdom \\ Published on 21 Mar 2016 | DOI: 10.14763/2016.1.398
}

\begin{abstract}
In 2011, a macaque monkey used a camera belonging to British photographer David Slater in Indonesia to take a self-portrait. The selfie picture became famous worldwide after it was published in the British media. In 2014 Slater sent a removal request to Wikimedia Commons, which indicated that the picture was in the public domain because it had been taken by the monkey and animals cannot own copyright works. While most of the legal analysis so far has been centred around US law, this article takes a completely different approach. Re-assessing jurisdictional issues, I examine the case from a UK and European perspective. The monkey selfie is of importance to internet policy: it has a lot to teach us about online jurisdiction. Under current originality rules, David Slater has a good copyright claim for ownership of the picture.
\end{abstract}

Keywords: Copyright, European law, Monkey, Selfie

\section{Article information}

Received: 14 Dec 2015 Reviewed: 02 Mar 2016 Published: 21 Mar 2016

Licence: Creative Commons Attribution 3.0 Germany

Competing interests: The author has declared that no competing interests exist that have influenced the text.

URL:

http://policyreview.info/articles/analysis/monkey-selfie-copyright-lessons-originality-photographs-and -internet-jurisdiction

Citation: Guadamuz, A. (2016). The monkey selfie: copyright lessons for originality in photographs and internet jurisdiction. Internet Policy Review, 5(1). https://doi.org/10.14763/2016.1.398

\section{INTRODUCTION}

On July 2011, news sources around the world were inundated with the image of a smiling monkey. The picture is that of a crested black macaque monkey in a national park of North Sulawesi, Indonesia. The picture was taken with the camera of British photographer David Slater, who was in the refuge on a three-day trip to take pictures of a troupe of monkeys. During the second day of shooting, Slater followed a troupe of 25 monkeys until they stopped at a place to rest, groom and play; he noticed that the simians were friendly and gregarious, and the braver members seemed interested in his photographic equipment. He initially setup one camera with 
a self-timer, but the monkeys took it away. After rescuing it, he positioned it in a different way. In his own words:

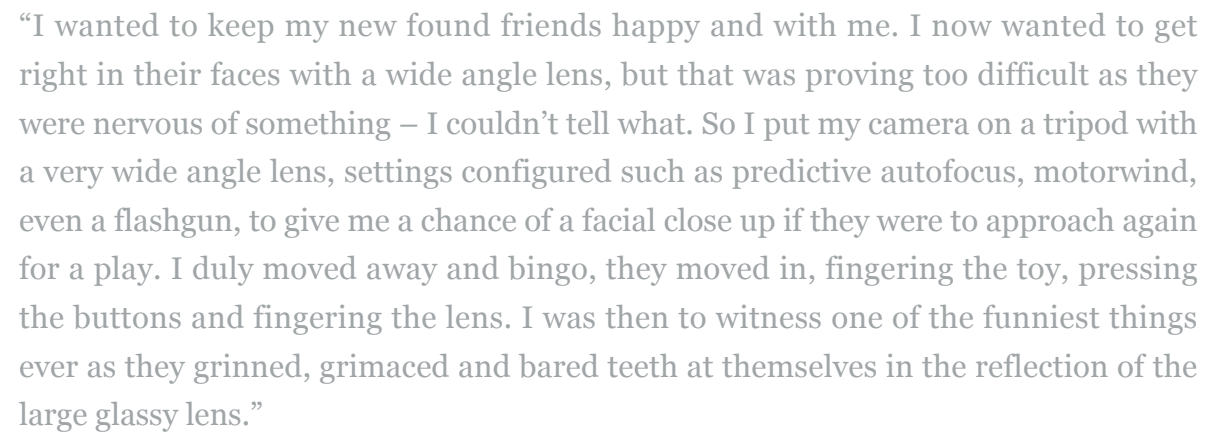

The session lasted thirty minutes and produced hundreds of pictures, but only a few were in focus and usable, but three of them in particular were spectacular. Slater selected these, and contacted the Daily Mail, which promptly published the story, which was then picked up by other news sources. The monkey pictures were an instant hit online, the smiling monkey (see Figure 1) particularly becoming incredibly popular in social media.

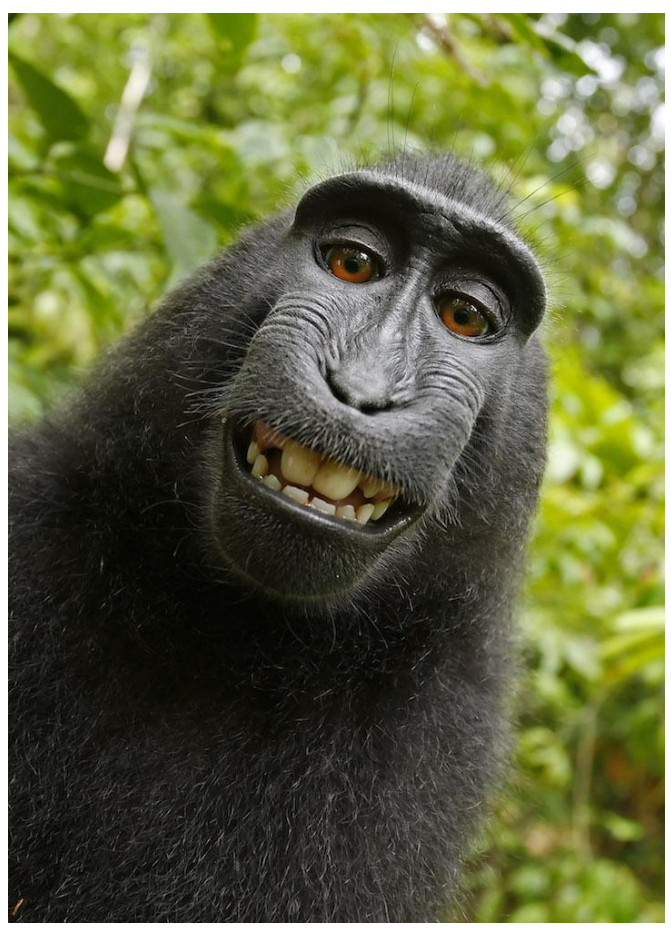

Figure 1: Monkey selfie (Wikipedia).

But the popularity of the pictures came with a price. In 2014 there was a dispute between Slater and Wikipedia, as the online encyclopaedia uploaded the picture and tagged it as being in the public domain. Without going into further legal detail, Wikipedia marked the picture with the following categorical statement: "This file is in the public domain, because as the work of a nonhuman animal, it has no human author in whom copyright is vested." Then in 2015, the People for the Ethical Treatment of Animals (PETA) sued Slater in a California court on behalf of the monkey to assert copyright over the picture, a case that has been resolved with the judge, declaring that the monkey is not an author within the meaning of the U.S. Copyright Act. 
The litigation following the picture has prompted a considerable amount of commentary online, with large numbers of people assuming that the picture does not carry copyright. With a few exceptions (Logue, 2014), most of the legal analysis so far has been centred around US law (Masnick, 2011; Schlackman, 2013), with even the U.S. Copyright Office weighing in the question by stating that animals cannot produce copyright, and giving as an example of noncopyrightable works a "photograph taken by a monkey" (Copyright Office, 2014). However, most of the above opinions seem to have missed an important element of the facts of the case, Slater is a British national and the picture was taken in Indonesia, so there is practically no reason why US copyright law should prevail.

To redress this oversight, this article will examine the case from a UK and European perspective. To do that we will quickly look at the jurisdictional issues of which law applies to lend strength to the European-centric analysis. Then we will look at the case law in the UK and Europe dealing with originality in photographs. We will conclude with the question of whether this case is of importance to internet policy, arguing that the monkey selfie has a lot to teach us about online jurisdiction.

\section{JURISDICTION ISSUES}

Before analysing whether copyright subsists in the picture, we need to determine which law applies. The fact that the picture was shared online has been an important element from the start of the case, even overshadowing the physical elements of the story, such as Slater's nationality. The subject of internet jurisdiction is one of the most complex areas of internet law because of the international nature of the network. Much has been written about this subject (Kohl, 2007; Spang-Hanssen, 2004; Trammell \& Bambauer, 2014), and the question of where things happen online tends to be a legal headache that courts have to unravel since the days of the famous Yahoo $v$ LICRA case in 200o. Thankfully, copyright jurisdiction tends to be rather more straightforward.

Copyright law is strictly national in nature (Goldstein, 2001), but there is an international system in place that allows creators to protect their works in other jurisdictions. As a general principle, a work subsists wherever it is originated (Berne Convention, Art 5(1)), and it originates in the country where it was first published (Berne Convention, Art 5(4)(a)). So while the picture was taken in Indonesia, it was first published in the UK through Caters News Agency, a picture and video licensing firm, which then granted permission for their publication in the British media. Given the above, and given the fact that Slater has repeatedly claimed exercise of his rights in the UK (as per Art. 5(2) of the Berne Convention), it would be more than fair to assume that UK copyright law would apply in this instance, as it is where the work originates. Even if we ignored the place of publication, courts seem very keen to exercise jurisdiction for their nationals (Van Eechoud, 2003), and courts in the UK have even heard cases from other jurisdictions, as it was famously done in Pearce $v$ Ove Arup.

Furthermore, the Court of Justice of the European Union (CJEU) has been erring mostly on the side of the creator when it comes to jurisdiction matters, and particularly when dealing with online infringement cases, such as with Pinckney $v$ Mediatech and Hejduk $v$ EnergieAgentur.

Given all of the above, it is baffling that any legal analysis would be conducted with anything other than UK and European copyright law in mind, and the aforementioned efforts to involve US copyright law analysis are inappropriate, perhaps done under the assumption that Slater was 
a US citizen. However, there is one reason why a US analysis on jurisdiction issues might be needed. As mentioned above, PETA has sued David Slater and his company Wildlife Photography to try to get the copyright of the image given to the monkey, which they identify by the name Naruto.

The case is Naruto $v$ Slater, where the plaintiff is PETA acting on behalf of Naruto as "his Next Friends". This case is not isolated, it seems to be part of a wider campaign by PETA to try to establish rights for animals, but it is still possible to analyse the litigation at face value as a copyright case, even though we suspect that the intention is not at all about to establish animal ownership rights. The plaintiffs claimed that the famous monkey selfie pictures "resulted from a series of purposeful and voluntary actions by Naruto, unaided by Slater, resulting in original works of authorship not by Slater, but by Naruto." They argued that had the picture been taken by a human, that person would have been declared the author and copyright owner; and while they recognise that Naruto is a monkey, they insisted that US copyright law is broad enough as to allow protection awarded to non-humans.

The judge came to a quick decision, and in January 2016 he dismissed the case based on the fact that the monkey cannot be considered an author for the purposes of the law and therefore it cannot own any copyright, so PETA cannot act on behalf of the monkey. While the judge agreed that the monkey had taken the pictures by "independent, autonomous action", he ruled that animals do not have standing in a court of law, and therefore cannot sue for copyright. The judge clearly states that the US Copyright Act does not extend the concept of authorship to animals and therefore Naruto is not an author.

It is interesting that the jurisdiction question was never an issue in this case, perhaps overshadowed by the authorship element of the case. PETA sued in a California court because Slater published a book called Wildlife Personalities using the self-publishing service Blurb, a Delaware company that ships all of its printed material from a San Francisco warehouse. The plaintiffs claim that this is enough to grant them standing in the US. While PETA accept that Slater is a UK citizen, and that his company is also based in the UK, they use the fact that Blurb is an American company to establish jurisdiction.

However, Blurb has a UK website that accepts payment in Great Britain Pounds (GBP), so it is entirely possible that Slater used that service thinking that it was based in the UK. In fact, when looking for the website from Britain, a search engine offers the UK version in the search results as default. Normal rules of jurisdiction indicate that using a .co.uk site, and paying in British pounds would not open one up to US jurisdiction only because the site is run by a US company. On the contrary, several CJEU cases (e.g., Pammer $v$ Schlüter and Hotel Alpenhof $v$ Heller) dealing with online jurisdiction have ruled that elements such as shipping to a jurisdiction, offering services in a national currency, and purchasing a country code top-level domain (ccTLD) is enough to establish jurisdiction in that country. That would mean that if Slater used the Blurb.co.uk website, he could not be easily forced to accede to a Californian court. PETA has offices in the UK, so they could have surely sued in an English court.

While Naruto v Slater could be used to try to establish US jurisdiction, it must be said that the decision is very narrow. Slater's lawyers filed a very concise motion to dismiss that is based on the fact that animals cannot sue for copyright, and Judge Orrick's decision deals almost entirely with that fact. While the judge makes a valid declaration that the monkey cannot sue because he cannot own the copyright, he never ruled on whether Slater is the owner of the picture, as this was never a part of the proceedings. The case rests on whether Naruto is a copyright owner, and here the judge decided correctly according to US law. But the judge was never asked to rule if 
the picture is in the public domain, if Slater is the author, or which jurisdiction applies. This was cleverly left out by the defendants, so the question of jurisdiction is still legally open to interpretation. Moreover, the US case does not preclude Slater litigating in the UK.

\section{ORIGINALITY}

Besides the PETA case, most of the legal arguments that have been made about the monkey photographs stem from the fact that the picture was uploaded to Wikipedia by a user sometime in 2011. Caters News Agency and David Slater contacted Wikimedia - the the organisation in charge of the online encyclopaedia - to remove the high-definition image, which they refused to do. Wikimedia posted the following statement in its transparency report:
"A photographer left his camera unattended in a national park in North Sulawesi, Indonesia. A female crested black macaque monkey got ahold of the camera and took a series of pictures, including some self-portraits. The pictures were featured in an online newspaper article and eventually posted to Commons. We received a takedown request from the photographer, claiming that he owned the copyright to the photographs. We didn't agree, so we denied the request."

Subsequent discussions on their website surrounding the posting of the picture continued to emphasise the fact that the monkey had taken the picture, and the issue was finally settled with the aforementioned declaration from the U.S. Copyright Office.

There are various problems with this interpretation. The commentary seems to assume almost as a matter of fact that there is no copyright in the picture because it was taken by the monkey, and therefore it belongs in the public domain. Most of the legal discussion elsewhere also engages in a US-centric interpretation of the law. Most of the American discussion has centred on the issue of originality and creativity; in Baltimore Orioles $v$ MLB Players Association the 7th Circuit court found that "[a] work is original if it is the independent creation of its author. A work is creative if it embodies some modest amount of intellectual labor." In Feist $v$ Rural Telephone, the US Supreme Court emphasised that "copyright protects only those constituent elements of a work that possess more than a de minimis quantum of creativity." Under these requirements, it is unlikely that the picture would have copyright.

However, as it is evident from the previous section, there is little reason to assume that this is a United States copyright case at all. Other than the PETA lawsuit, there is no legal reason why we should consider the U.S. Copyright Office in this instance. The U.S. Copyright Office is not a court of law, and their declaration is part of a guidance booklet that has no legal value. Moreover, the declaration is only for registration purposes, but registration is not needed in international copyright law as per the Berne Convention. In fact, registration is only needed in the United States for enforcement purposes, but, here is the interesting part, as the picture was taken in Indonesia it is exempt from registration according to $\S 411$ of the US Code because it is not a "United States work" as defined by §101. Furthermore, Slater registered several monkey selfie pictures in 2012 with the U.S. Copyright Office, which lends strength to the argument that the declaration is mostly irrelevant.

So given the above, and considering that the picture was first published in the UK, then we should look at it from a UK and European perspective, as the scope of copyright law is 
harmonised across the continent. Surprisingly enough, the fact that the monkey pushed the camera button is largely irrelevant when it comes to the matter of copyright in photographs. Copyright protection is awarded to a photograph as an artistic work when it fulfils the requirement of originality, and most case law has been trying to determine precisely where the threshold of originality lies (Rosati, 2013). The problem with pictures, as opposed to other creative works subject to copyright such as literary works, is that they can often be produced mechanically, automatically, not truly reflecting true originality, "and more often than not without any effort or mental input" (Harms, 2013). Modern photography in particular is mostly a matter of pressing a button and allowing the computer inside the camera or mobile phone to make all of the decisions about aperture, angle, light and focus.

The test for originality has shifted away in the last few years from so-called skill and labour test to a more personal definition, and in particular, the originality requirement has become very different to that found in the US as per Feist (Gervais, 2002). For years, the level of originality had remained roughly the same in the UK since Walter $v$ Lane and Express Newspapers $v$ News UK. In Walter $v$ Lane, a set of hand-written notes was found to involve "considerable intellectual skill and brain labour". Under skill and labour tests, the amount of work that went into the creation of a work would have quite a lot of bearing on whether a work would be subject to copyright. One could argue that under this test, the monkey picture would probably not be considered original.

However, the CJEU truly moved the definition of originality in Infopaq v Danske Dagblades, where the Danish news clipping service Infopaq International was taken to court by the Danish newspaper association over its reproduction of news cuttings for sale to its clients. The clipping process involved a data capture process consisting of scanning images of original articles, the translation of those images into text, and the creation of an 11-word snippet for sale to Infopaq's clients. The court had to determine whether these snippets were original enough, as the process was highly mechanised. The Court decided in the end a new definition of originality, namely that the work must be the "author's own intellectual creation", and ruled in favour of giving copyright to the work. One could argue that Infopaq would only apply to literary works and the arrangement of snippets, but in the case of BSA $v$ Ministry of Culture, the CJEU decided to apply the ruling to other works, specifically naming a graphic user interface in a computer programme as subject to copyright protection because it was the "author's own intellectual creation" (Griffiths, 2011).

Selection is an important element in general in art, and we see this in several instances of "found objects" in which everyday objects selected by the artists can act as an important expression of creativity, such as Duchamp's Fountain. This expression of the creative process through selection has been recognised by the courts as worthy of copyright protection in the case of Lucasfilm $v$ Ainsworth, where Mann J considered that a pile of bricks in exhibition at the Tate Modern museum could be classed as a sculpture for the purpose of copyright protection, but that an identical pile of bricks dumped at the end of his driveway plainly is not. One can conclude from this that purpose and selection can indicate originality.

When it comes to photographs, the test for originality has been moving in similar ways. Art 6 of the Copyright Term Directive (93/98/EEC) usefully explains that "Photographs which are original in the sense that they are the author's own intellectual creation shall be protected..." The Directive's preamble defines original as a work that is the "author's own intellectual creation reflecting his personality". In particular, the CJEU applied the originality test in Painer $v$ Standard Verlags $\mathrm{GmbH}$. This case involves a portrait pictures of Natascha Kampusch, an 
Austrian woman famous for having been abducted and held captive for eight years in a cellar. Professional photographer Eva-Maria Painer had taken pictures before the kidnapping, which were used by law enforcement to search for the missing girl. After Kampusch escaped, Painer's pictures were used by the Austrian media, as it was the only public portrait of Kampusch; this was done without Painer's permission, and even without attribution. Painer sued for copyright infringement, and the case made it all the way to the CJEU on the question of whether a simple portrait could have copyright protection. The Court restated the test in Infopaq, but it added a useful set of rules, saying that copyright in a photograph subsists if "the author was able to express his creative abilities in the production of the work by making free and creative choices". They commented that the following are indicative of a creative choice:

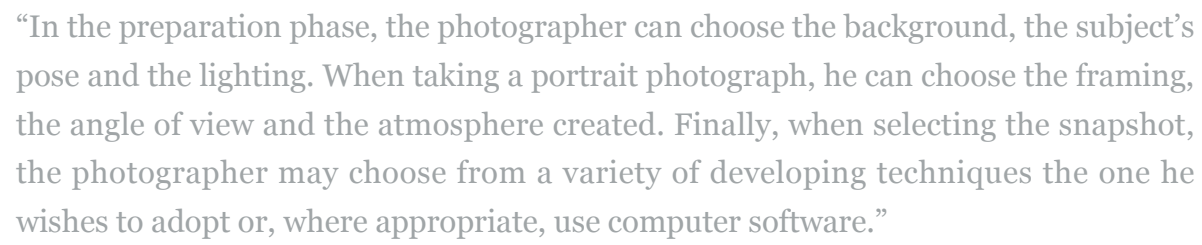

UK courts have also had some input with regards to the originality in photographs. While the arrangement of pictures into a collage was not considered to be enough to warrant copyright protection in Creation Records $v$ News Group, other cases have served to establish that input from the photographer can be enough to warrant copyright protection. In the case of Temple Island Collections $v$ New English Teas, which involved an iconic mostly black and white image of the UK Parliament and Big Ben with a bright red bus travelling across Westminster Bridge. The claimant owned the photograph, which was used in London souvenirs, and the defendant is a tea company that created a similar picture for a publicity campaign. The judge had to determine whether the picture had copyright, and he concluded that when it comes to photography the composition is important, namely the angle of shot, the field of view, and the bringing together of different elements at the right place and the right time are enough to prove "skill and labour/intellectual creation", and therefore should have copyright.

\section{DOES THE MONKEY SELFIE HAVE COPYRIGHT?}

Given all of the elements discussed above, it would appear evident that at the very least there is a strong case to be made in favour of the picture having copyright regardless of who pressed the button.

What is important for the legal analysis is the sequence of events. In most of the interviews and re-telling of the story, Slater has maintained that he placed the camera on a tripod in order to get the monkeys to interact with it, as just leaving the camera lying around had prompted them to take it away. In the original account of the incident, what happened was not only an isolated act of a monkey taking a picture, it took hundreds. David Slater told the newspapers: 'He must have taken hundreds of pictures by the time I got my camera back, but not very many were in focus. He obviously hadn't worked that out yet.'

So there is an element of arrangement of the equipment that is consistent with the requirements imposed in both Temple Island Collections and Painer. The choosing of angle, the selection of focus, and placing the camera in a tripod all lead us to think that there was a deliberate effort to 
try to get a picture that reflects the personality of the author. In Painer in particular, CJEU ruled that copyright subsists in a photograph if it is the intellectual creation of the author, reflecting his personality, and expressing her free and creative choices in the production of the photograph. This can be expressed in manner of creative choices, such as the lighting, background, pose, framing, angle and atmosphere (Logue, 2014). Similarly, the use of computer software to develop the pictures can also provide evidence of originality. While the monkey pressed the button, everything else was performed by Slater, including placing the camera on a tripod, which indicates a choice of angle and background.

But perhaps more important is what happens after. If there were hundreds of pictures, then it was up to Slater to make a selection of the ones that were worthy of publication, and Infopaq is clear that a selection process can determine the presence of originality, as the CJEU gave a lot of importance to the intellectual act of selection and arrangement of text snippets. Talking about word selection, the court said:

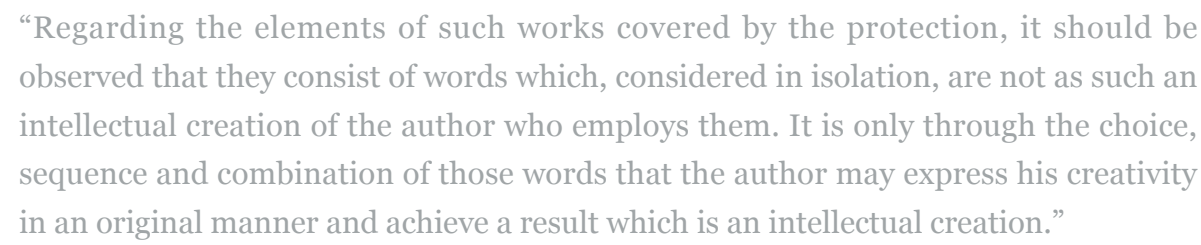

So there was an intellectual exercise in the selection of the hundreds of pictures, enough in my mind to meet the requirement in the law of an intellectual creation "reflecting his personality". This is evidenced by the existence of several blurred pictures that prove a selection process behind the iconic selfie.

There is another element that favours the pro-copyright argument. UK copyright law is unique (Stokes, 2014; Lai, 1999) in containing a provision for copyright created by non-humans. While the law is silent with regards to simian copyright, it has an area that we could use as an analogy, computer-generated works. Section 9(3) of the Computer, Designs and Patents Act (CDPA) states that the author of a literary, dramatic, musical or artistic work which is computergenerated "shall be taken to be the person by whom the arrangements necessary for the creation of the work". The law therefore is more than willing to accept that a non-human entity can generate a work subject to copyright protection as long as the author of the process that led to the creation of the work can be identified. Moreover, because modern photography relies heavily on the computer settings within the camera, this provision could apply to a large amount of photography in general. Paul Harris (Harris, 2014) explains:

"Being a digital camera, the image created when the button is pushed is actually computer-generated. No longer is a roll of film required, carefully shielded from the light so as not to expose it. It all depends on that all-pervading microchip. In that sub-section, the author is taken to be the person who makes the arrangements for the creation of the work. [... A] digital camera creates a computer-generated work (the image in front of it), and the author is, in most cases, the person who switches the camera on (i.e. makes the arrangements for), and the computer-generated image is created by the pressing of the shutter button." 
Any way you look at it, European law is more willing to warrant copyright protection to a creator that exercises a series of creative choices that reflect their personality, so the mechanical process of pressing the button is less important. This is also a common sense approach: we universally recognise that the mechanical act of taking a picture itself is not what creates the subsistence of copyright, what matters is what happens before and after. Similarly, the use of mechanical triggers and/or automated delays does not invalidate copyright and throws the item into the public domain.

For the sake of completeness, this analysis largely ignores the Indonesian law element for various reasons, namely because none of the parties involved seem to be interested in dealing with that jurisdiction. This is a practical matter, when on holiday abroad, you would not expect to have to travel to the country where you took the pictures in case of copyright infringement. The Berne Convention gives us enough indication that we can continue to safely ignore the Indonesian element. However, it may be interesting to point out that Art 1 of the Indonesian copyright law defines an author as a person whose work "is produced, based on the intellectual ability, imagination, dexterity, skill or expertise manifested in a distinctive form and is of a personal nature". This definition is very close to the European standard as identified in the case law, and it would be possible to argue strongly that Slater would also be the copyright owner in that jurisdiction.

\section{CONCLUSION}

It is hoped that the analysis provided will help to dismantle some of the inaccuracies regarding the monkey selfie case, and will prompt some discussion about the jurisdictional complexities and the debates around originality and non-human authorship in future cases.

Based on the facts and the relevant rulings in the UK and Europe, there is a very strong argument to be made for the subsistence of copyright in the monkey selfie picture; David Slater can safely make the claim that he owns the copyright in the picture in the UK. The fact that $\mathrm{Mr}$ Slater followed the troupe of monkeys and patiently gained their trust allowed him to stage the scene that would favour placing a camera and setting it up in a manner that would attract a monkey and make it snap a picture. The subsequent selection process and the development of the image can also indicate the presence of copyright in the picture.

But beyond the mere interest from a copyright law perspective, the monkey selfie case is of importance to internet policy issues as a whole because it serves to highlight the prevalence of American-centric legal interpretation of online conflicts. While most newspaper articles that depicted the monkey initially were clear that the picture had been taken in Indonesia, and that David Slater is British, a large part of the legal analysis tended to ignore this and applied US jurisdiction immediately. This is something that tends to be replicated in other instances where there is no reason to make a legal analysis based on American standards. And even when commenting about European developments, it is not uncommon to read analysis that concentrates on describing the issues through an American lens, as if US legal principles applied everywhere. This can be seen in discussion about recent data protection rulings by the CJEU, such as Google Spain $v$ AEPD, or the Schrems v DPC decision, where commentators emphasise the freedom of speech elements, ignoring the rich tradition of privacy protection in Europe. 


\section{REFERENCES}

Berne Convention for the Protection of Literary and Artistic Works.

Bridy, A. (2012). Coding Creativity: Copyright and the Artificially Intelligent Author. Stanford Technology Law Review, 5, 1-28.

Council Directive 93/98/EEC of 29 October 1993 harmonizing the term of protection of copyright and certain related rights.

Gervais, D. (2002). Feist Goes Global: A Comparative Analysis of the Notion of Originality in Copyright Law. Journal of the Copyright Society of the USA. 49, 949.

Goldstein, P. (2001). International copyright: principles, law, and practice. Oxford University Press.

Griffiths, J. (2011). Infopaq, BSA and the 'Europeanisation' of United Kingdom Copyright Law. Media \& Arts Law Review, 16.

Griffiths, J. (2013). Constitutionalising or harmonising? The Court of Justice, the right to property and European copyright law. European Law Review, 38, 65-78.

Harms, L. (2013). "Originality" and "reproduction" in copyright law with special reference to photographs. Potchefstroomse Elektroniese Regsblad 16(5) 1-28.

Harris, P. (2014) Cheeky Monkey. Pillsbury Law Newsletter, http://bit.ly/1NNTJRR.

Karapapa, S. (2012). Digital private copying: The scope of user freedom in EU digital copyright. New York: Routledge.

Kohl, U. (2007). Jurisdiction and the Internet: a study of regulatory competence over online activity. Cambridge: Cambridge University Press.

Lai, S. (1999). Substantive issues of copyright protection in a networked environment. Information \& Communications Technology Law 8(2), 127-139.

Logue, F. (2014). Monkey see, Monkey do. Gazette of the Law Society Ireland 108(8), 27-29.

Masnick, M. (July 3, 2011). Monkeys Don't Do Fair Use; News Agency Tells Techdirt to Remove Photos. Techdirt, http://bit.ly/1IJfxoG.

Morgan, C. (2015). On the digitisation of knowledge: copyright in the light of Technische Universitat Darmstadt v Eugen Ulmer KG. European Intellectual Property Review, 37(2), 107111.

Newell, B. C. (2010). Independent Creation and Originality in the Age of Imitated Reality: A Comparative Analysis of Copyright and Database Protection for Digital Models of Real People. Brigham Young University International Law \& Management Review, 6, 93.

Rahmatian, A. (2012). Temple Island Collections v New English Teas: an incorrect decision based on the right law? European Intellectual Property Review, 34(11), 796-799.

Rhee, C. (1998). Urantia Foundation v. Maaherra. Berkeley Technology Law Journal, 13, 69. 
Rosati, E. (2010). Originality in a Work, or a Work of Originality: The effects of the Infopaq decision. Journal of the Copyright Society of the USA. 58, 795.

Rosati, E. (2013). Originality in EU copyright: full harmonization through case law. Cheltenham, UK: Edward Elgar.

Schlackman, S. (2013). The Telegraph is Wrong about the Monkey Selfie. Art Law Journal, http://bit.ly/1TJzpBe.

Spang-Hanssen, H. (2004). Cyberspace and International Law on Jurisdiction: Possibilities of Dividing Cyberspace into Jurisdictions with Help of Filters and Firewall Software.

Copenhagen: Djof Publishing.

Stokes, S. (2014). Digital copyright: law and practice. Bloomsbury Publishing.

Trammell, A. M., \& Bambauer, D. E. (2014). Personal Jurisdiction and the Interwebs. Cornell Law Review, 100, 1129.

United States Copyright Office (2014). Compendium of US Copyright Office Practices. 3rd Edition, § 313.2, http://1.usa.gov/1TJzkxw (PDF).

Van Eechoud, M. M. M. (2003). Choice of law in copyright and related rights: alternatives to the Lex Protectionis. The Hague: Kluwer Law International.

Xanthoulis, N., \& Georgiades, A. (2014). Football Dataco and Others v. Yahoo! UK Ltd and Others (C-604/10)-Case Summary and Analysis. Landmark IP Decisions of the Court of Justice of the EU, Larcier, Brussels.

\section{LIST OF CASES}

Baltimore Orioles, Inc. v. Major League Baseball Players Association, 805 F.2d 663 (7th Cir. 1986).

Case C-393/o9 Bezpečnostní softwarová asociace - Svaz softwarové ochrany (BSA) v Ministry of Culture of the Czech Republic [2010] ECR I-13971.

Case C $\square$ 145/10 Eva-Maria Painer v Standard Verlags GmbH \& Others [2013] (CJEU, 7 March 2013).

Case C-131/12 Google Spain SL, Google Inc. v Agencia Española de Protección de Datos (es), Mario Costeja González [2014] (CJEU, 13 May 2014).

Case C $\square$ 5/o8 Infopaq International A/S v Danske Dagblades Forening [2009] ECR I-06569.

Case C-362/14 Maximillian Schrems v Data Protection Commissioner [2015] (CJEU 6 October 2015).

Case C $\square$ 441/13 Pez Hejduk v EnergieAgentur.NRW GmbH [2013] (CJEU 22 January 2015).

Case C $\square$ 170/12 Peter Pinckney v KDG Mediatech AG [2013] (CJEU 3 October 2013).

Creation Records Ltd. and Others v News Group Newspapers Ltd [1997] EMLR 444.

Express Newspapers v News (UK) [1990] 1 WLR 1320. 
The monkey selfie: copyright lessons for originality in photographs and internet jurisdiction

Feist Publications, Inc., v. Rural Telephone Service Co., 499 US 340 (1991).

Joined cases C-585/08 and C-144/o9 Peter Pammer v Reederei Karl Schlüter GmbH \& Co. KG and Hotel Alpenhof GesmbH v Oliver Heller [2010] ECR I-12527.

Lucasfilm Limited and others v Ainsworth and another [2009] EWCA Civ 1328.

Naruto, et al. v. Slater, et al., no. 15-CV-04324 (N.D. Cal. January 28, 2016).

Pearce v Ove Arup Partnership Ltd \& Ors [2001] EWHC Ch 481.

Temple Island Collections Ltd v New English Teas Ltd and Another (No. 2) [2012] EWPCC 1. Walter v Lane [1900] AC 539.

Yahoo! Inc. v. LICRA and UEJF (2006) 433 F.3d 1199. 